\title{
Recurrent Multi-Drug-Resistant Tuberculosis with Unilateral Destroyed Lung in Pregnancy: A Case Report
}

\author{
Irene Sinta Febriana, Sayogo Atikah, Sri Pudyastuti \\ Department of Obstetrics and Gynecology, Persahabatan National Pulmonary Hospital, \\ Jakarta, Indonesia \\ Korespondensi: irene.sintafebriana@gmail.com
}

\begin{abstract}
Background: Multi-drug-resistant Tuberculosis (MDR-TB) remains a public health problem in developing countries such as Indonesia. The extensive parenchymal damage due to MDR-TB could manifest as an irreversible destroyed lung, leading to respiratory and also cardiovascular complication. Its occurrence in pregnancy is uncommon but is highly associated with higher mortality and morbidity for both maternal and fetal.

Case Report: We report a case of 24 year old primigravida in National Respiratory Center Hospital, diagnosed with an unilateral destroyed lung due to MDR-TB in pregnancy at 32 weeks of gestational age. On initial presentation, she reported fatigue, nausea, night sweats, chronic dyspnoe and was found to have complete left destroyed lung. Her disease was managed during pregnancy using long-term oxygen therapy despite persistent desaturation.

Conlusion: Aside from frequent monitoring, prolonged oxygen therapy might benefit the chronic hypoxia condition in gestational destroyed lung due to previous MDR-TB infection, for preventing maternal-fetal mortality and morbidities, such as respiratory failure and IUGR.
\end{abstract}

\section{Tuberkulosis MDR rekuren dengan Kerusakan paru unilateral dalam kehamilan : Sebuah laporan kasus}

\begin{abstract}
Abstrak
Latar Belakang: Tuberkulosis Multi-drug-resistant (TB-MDR) tetap menjadi masalah kesehatan pada negara berkembang, seperti Indonesia. Kerusakan parenkin luas yang diakibatkan oleh infeksi TB-MDR dapat bermanifestasi sebagai kerusakan paru ireversibel, dengan komplikasi respiratorik dan kardiovaskular. Kejadian kerusakan paru akibat TB-MDR dalam kehamilan jarang terjadi, namun berdampak pada peningkatan mortalitas dan morbiditas pada janin dan ibu.

Laporan Kasus: Studi ini melaporkan kasus perempuan primigravida 24 tahun didiagnosa dengan kerusakan paru unilateral akibat infeksi TB-MDR pada kehamilan 32 minggu di RS Pusat Paru Nasional. Pada pemeriksaan awal, didapatkan pasien mengeluhkan kelelahan kronik, nausea, keringat malam, sesak kronik dan didapatkan memiliki kerusakan paru kiri komplit. Keadaan pasien dalam kehamilan ditatalaksana dengan terapi oksigen jangka panjang untuk mengatasi desaturasi persisten

Kesimpulan: Di samping pengawasan ketat, terapi oksigen jangka panjang dapat menjadi tatalaksana utama untuk kondisi hipoksia kronik pada kerusakan paru dalam kehamilan akibat infeksi lama TB-MDR untuk mencegah morbiditas dan mortalitas ibu dan janin, seperti gagal napas dan pertumbuhan janin terhambat (PJT).
\end{abstract}




\section{Introduction}

Multi-drug resistant tuberculosis (MDR-TB) is defined as tuberculosis infection resistant to at least rifampicin and isoniazid. Indonesia, with approximately 6,800 new cases every year, is one of the 27 MDR-TB high burden countries worldwide. ${ }^{1} 13 \%$ of MDR-TB cases in Indonesia have been received previous TB treatment. ${ }^{2}$ As much as 1.860 patients were confirmed MDR-TB in Indonesia. ${ }^{3}$ MDR-TB affects young adults, including child-bearing age women. ${ }^{4}$ The understanding of teratogenic properties of second-line drugs is not fully established yet negligence of treatment would lead to higher risk of maternal and fetal mortality and morbidity.

If not well managed, the extensive parenchymal damage of the infection could manifest as destroyed lung, defined as a total destruction of the lung secondary to recurrent or chronic lung infection. A destroyed lung causes chronic airway obstruction as well as restrictive change, pulmonary hypertension, and left-right shunt. The destroyed lung architecture is easily colonised by bacteria and fungi, increasing the risk of recurrent infection thus higher morbidity and mortality. ${ }^{5,6}$

\section{Case presentation}

A 26-year-old primigravida at 32-week period of gestation (POG) presenting with progressive dyspnea (12 hours) was admitted. Other symptoms were chest pain, productive cough, fever, and swollen extremities. She had history of MDR -TB and had been completed her treatment for 6 months prior to admission and now in long term oxygen therapy. She was consulted to Ob-Gyn due to contraction (4 hours) without any vaginal discharge.

On admission, she was fully conscious, blood pressure was $99 / 65 \mathrm{mmHg}$, heart rate was $110 / \mathrm{min}$, temperature was $37.5{ }^{\circ} \mathrm{C}$, respiratory rate was $26 / \mathrm{min}$, and oxygen saturation was $83 \%$ at room air and was $92 \%$ at $4 \mathrm{lpm}$ by nasal cannula. She weighed 35 $\mathrm{kg}$ and her height was $150 \mathrm{~cm}$ (body mass index $=15.5 \mathrm{~kg} / \mathrm{m}^{2}$ ). Pale conjunctiva and enlarged bilateral submandibular lymph node were positive. Thorax examination revealed collapsed left hemithorax, decreased left vesicular sound, bilateral ronchi, and trachea was deviated to the left with coarse crepitations and bronchial breath sounds over left hemithorax. Fundal height was $23 \mathrm{~cm}$, cephalic presentation, fetal heart rate at 148 / min. Contraction was observed four times every 10 minutes for 40 seconds.

Cardiotocography result was category 1. Ultrasound revealed EFW 1703 gr,BPD 82, HC 287, AC 276, FL 61, showing accordance to 32-33 wga with reduced amniotic volume AFI 8.5, SDAU 2.8, PI 1.08, MCA PI 1.52, CRP >1. Blood test revealed microcytic hypochromic anemia with $\mathrm{Hb}$ of $7.8 \mathrm{~g} / \mathrm{dl}$, hypoalbuminemia $(2.4 \mathrm{~g} / \mathrm{dl})$, and hyponatremia $(125 \mathrm{mEq} / \mathrm{L})$. Chest x-ray showedinfiltrates at right lung, bronchiectasis, collapsed left lung with pleural line, fibrocystic changes, complete shift of the tracheal air column to the left and compensatory hyperinflation of the right lung (figure 1). Sputum test revealed resistance to Rifampicin.Gene Xpert showed positive result.

Doppler limb ultrasound revealed oedema with no abnormality of the vein. Echocardiography result showed dilatation of right atrium and right ventricle, normal LVEF of $67 \%$, reduced right ventricle contractility (TAPSE $0.42 \mathrm{~cm}$ ), severe tricuspid regurgitation with high probability of pulmonary hypertension, and moderate pulmonary regurgitation. The assesment was preterm labor contraction with tocolytic score of 4 , reccurent multi-drug tuberculosis with unilateral destroyed lung.

Treatments given were daily intravenous fluid, parenteral nutrition, 4 course of 


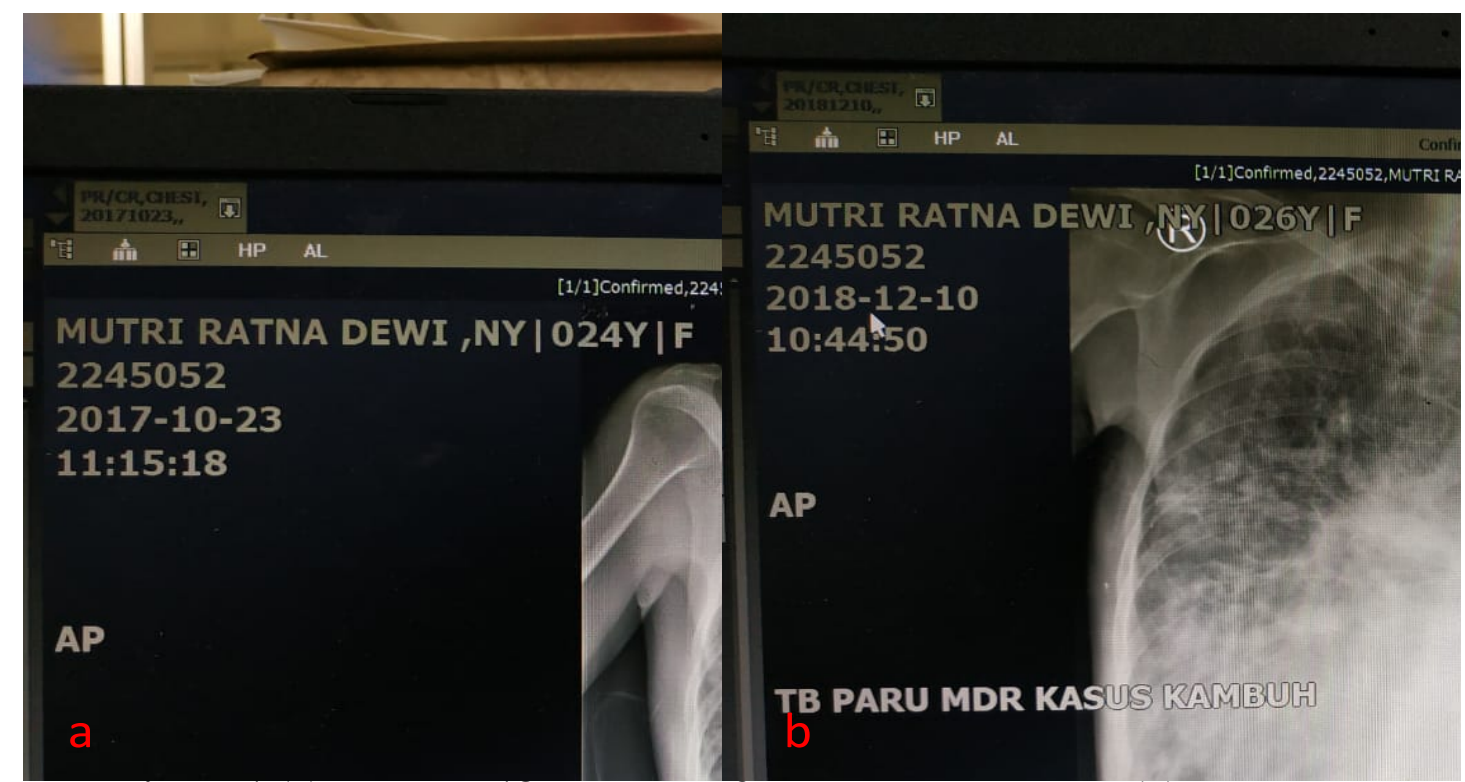

Figure 1 (a) x-ray on 18th month of MDR-TB treatment. (b) current xray showing collapsed left lung and pleural line

dexamethasone for fetal lung maturation, intravenous ampicillin-sulbactam, oral treatments of albumin, folic acid, calcium, cholecalciferol, ferrous sulphate, sodium chloride, vitamin B complex. She received blood transfusion (2 units packed red cells) with $\mathrm{Hb}$ target of $11 \mathrm{~g} / \mathrm{dl}$. Taken care by Pulmonology Department, patient was given oxygen therapy, screening and sputum culture were negative, acid-alcohol fast-bacilli were positive on Ziehl-Neelsen staining.

3 days later she delivered spontaneously after preterm premature rupture of membrane, with baby weighing $1700 \mathrm{gr}$ (centile $10^{\text {th }}-50^{\text {th }}$, Intergrowth chart), with good Apgar score of 7 and 8,with reduced clear amniotic fluid. No major congenital anomalies has seen in baby. The baby was admitted to NICU with CPAP PEEP 7, FiO2 21\% and saturation of $97 \%$. The baby was discharged 35 days after hospitalizations, given prophylactic isoniazid. Mother and babies were fine on follow-up 12 weeks after delivery, mother was given longterm oxygen therapy (LTOT); high-flow nasal canula, portable oxygen delivery with oxygen conserving devices.

\section{Discussion}

MDR-TB treatment in pregnancy is a very challenging condition in which no therapy guideline has been established. Almost all second line anti-TB drugs fall under category C except aminoglycosides (category D). Treatment is individualized based on drug resistance pattern. There have been studies promoting the benefits of treatment that outweigh the risks to the mother and fetus. ${ }^{7,8}$ However, large-scale study about efficacy and toxicity is still absent. On the other hand, late initiation on treatment was reported to have higher rate of preterm labor and neonatal complications compared to early treatment or non-TB pregnant patients and there is higher risk of postpartum vertical transmission due to slower conversion rate in MDR-TB case..$^{9,10}$ Patient's history of MDR-TB was the origin of her left destroyed lung, which further complicated her pregnancy. Destroyed lung often leads to chronic hypoxemia, whose main effect to the fetus is failure to achieve its potential growth, i.e. intrauterine growth restriction (IUGR). IUGR fetus have higher risk of distress, asphyxia, and 
perinatal mortality and morbidity, as well as fetal origins of adult disease for longterm complications. ${ }^{11}$ Patient's oxygen saturation in room air was only $83 \%$, thererefore she was given long-term oxygen therapy and upon admission she was with $4 \mathrm{lpm}$ of oxygen through nasal cannula, with target oxygen saturation was maximum 92\%.In practice, real-time monitoring of $\mathrm{PaO}_{2}$ is not usually possible and therefore a target $\mathrm{SaO}_{2}$ range of $88 \%-92 \%$ is now generally accepted for those patients at risk of hypercapnia. Allowing for individual variations in the oxygen dissociation curve, these will correct hypoxia to a safe level and minimize the risk of oxygen-induced hypercapnia.

Although there was reduced amniotic fluid which could be initial symptom of growth restriction, fetal ultrasound still showed normal growth and activity. This shows that oxygen therapy might be beneficial to prevent further sequalae of fetal hypoxia. This is in accordance with Nicolaides, et al reporting the benefit of maternal oxygen therapy for increasing fetal $\mathrm{pO} 2$ to ameliorate growth restriction. ${ }^{12}$ While patient also had anemia of chronic disease as another risk factor of fetal hypoxia, it is known for less deleterious effect for the fetal since higher oxygen affinity of fetal haemoglobin will be compensatory. Fetus is also able to increase cardiac output to increase transplacental oxygen transfer by interfering with the iron metabolism of the mother. ${ }^{11}$

Aside from maintaining adequate oxygen, decision about whether to conserve or terminate the pregnancy in this case was also challenging. The decision case should be based on IUGR management approach. Once small fetus is identified, measurement of UtA PI, UA PI, MCA PI, and CPR should be performed to distinguish between SGA and IUGR, as well as to classify the stage of growth restriction. In this case, reduced amnion fluid could be the sign of mild placental insufficiency, which fall into first stage of IUGR. Monitoring should be performed weekly and labor induction should be offered at 37 wga. ${ }^{13}$ However, this patient had preterm premature rupture of membrane and had preterm birth.

Pneumonectomy is recommended for destroyed lung butplanned surgery is recommended due to higher morbidityand mortality in emergency cases; this explains there's no plan from Pulmonology Department yet about the surgery because it was suggested to patients whose contralateral lung is healthy, with no sign of reccurency or relaps.

\section{Conclusion}

Aside from frequent monitoring, long-term oxygen therapy might benefit the chronic hypoxia condition in gestational destroyed lung due to previous MDR-TB infection, for preventing maternal-fetal mortality and morbidities, such as respiratory failure and IUGR.

\section{Acknowledgements}

MDR-TB treatment are fully covered by National Health Insurance Program of Indonesia. No conflict of interest existed among authors.

\section{References}

1. World Health Organization Indonesia. MDR TB Indonesia Update 2016 [online]. World Health Organization Indonesia: Indonesia; 2018 [accessed December 2018]. Available from: http:// www.searo.who.int/indonesia/topics/tb/ indTBmdr2016/en/.

2. World Health Organization. Global Tuberculosis Report 2018 [online]. World Health Organization: France; 2018 paccessed 2018]. Available from: http://apps.who.int/iris/bitstream/hand 
le/10665/274453/9789241565646-eng. pdf?ua $=1$

3. Center of Data and Information of Health Ministry of Republic of Indonesia. Tuberkulosis: Temukan, obati sampai sembuh [online]. Health Ministry of Indonesia: Jakarta; 2018 [accessed December 2018]. Available from: http:// www.depkes.go.id/resources/download/ pusdatin/infodatin/InfoDatin-2016-TB. pdf

4. Ormerod P. Tuberculosis in pregnancy and the puerperium.Thorax. 2001 Jun; 56(6):494-9.

5. Jo YS, Park JH, Lee JK, Heo EY, Chung HS, Kim DK. Risk factors for pulmonary arterial hypertension in patients with tuberculosis-destroyed lungs and their clinical characteristics compared with patients with chronic obstructive pulmonary disease. Int J Chron Obstruct Pulmon Dis. 2017 Aug;12:2433-2443. doi: 10.2147/COPD.S136304

6. Crespo GM, Martinez AF, Gonzales CFJ. Destroyed lung complicated with empyema. Imaging in Medicine. 2016; 8(4): 113-115.

7. Palacios E, Dallman R, Munoz M, Hurtado R, Chalco K, Guerra D, et al. Drug-resistant tuberculosis and pregnancy: Management and treatment outcomes of 38 cases in Lima, Peru. Clin Infect Dis. 2009 May; 48(10): 14131419. doi:10.1086/598191

8. Drobac PC, del Castillo H, Sweetland A, Anca G, Joseph JK, Furin J, Shin S. Treatment of multidrug-resistant tuberculosis during pregnancy: long-term follow-up of 6 children with intrauterine exposure to second-line agents. Clin Infect Dis. 2005 Jun; 40(11): 1689-92. Epub 2005 Apr 18.

9. Figueroa-Damaian R, Arredondo-Garcia JL. Pregnancy and tuberculosis: influence of treatment on perinatal outcome. $A m J$ Perinatol. 1998; 15: 303-306.
10. Shin S, Guerra D, Rich M, Seung KJ, Mukherjee J, Joseph K, et al. Treatment of Multidrug-Resistant Tuberculosis during Pregnancy: A Report of 7 Cases. Clinical Infectious Diseases. 2003; 36(8): 9961003. https://doi.org/10.1086/374225

11. Hutter D, Kingdom J, Jaeggi E. Causes and Mechanisms of Intrauterine Hypoxia and ItsImpact on the Fetal Cardiovascular System: A Review. International Journal of Pediatrics. 2010;401323. doi:10.1155/2010/401323

12. Nicolaides KH, Bradley RJ, Soothill PW, Campbell S, Bilardo CM, Gibb D. Maternal Oxygen Therapy for Intrauterine Growth Retardation. The Lancet. 1987; 329(8539): $942-945$.

13. Figueras f, Gratacos E. Update on the Diagnosis and Classification of Fetal Growth Restriction and Proposal of a Stage-Based Management Protocol. Fetal Diagn Ther. 2014; 36: 86-98. https://doi. org/10.1159/000357592 